\title{
Gender and Detective Literature: The Role of Miss Marple in Agatha Christie's The Body in the Library
}

\author{
Berna Köseoğlu \\ Kocaeli University, Department of English Language and Literature \\ Umuttepe Campus, 41380, Kocaeli, Turkey \\ E-mail: berna.koseoglu@kocaeli.edu.tr
}

Received: 01-10- 2014

Published: 01-05- 2015
Accepted: 18-12- 2014

doi:10.7575/aiac.ijalel.v.4n.3p.132
Advance Access Published: December 2014

URL: http://dx.doi.org/10.7575/aiac.ijalel.v.4n.3p.132

\begin{abstract}
Considering the rise of detective fiction in the twentieth century, it is clear that Agatha Christie plays a very important role in the development of detective novels. As a female author, she achieves producing distinctive works and creating remarkable sleuths. Although her works reflect the conventional characteristics of detective narrative, what makes her fiction distinguished is the female sleuth Miss Marple, who is an unconventional character in terms of her position in Christie's writings. Particularly, in her The Body in the Library, the character, Miss Marple, comes to the fore as an amateur investigator, who surpasses the power of patriarchal society. Her appearance among the male sleuths changes the route of the investigation when she accomplishes attaining the truth about the murder and revealing the mystery of crimes. In this sense, in a male-dominated setting, Miss Marple establishes order and morality in society and proves that women are as intelligent, reasonable and challenging as men. In this paper, Christie's contribution to detective fiction by means of her character, Miss Marple in The Body in the Library, will be highlighted. Moreover, the stratagems Miss Marple employs to solve the uncertainties about the criminal case will be explored so as to emphasize the conflict between women and men not only in society but also in the field of criminal investigations, therefore together with her talents in the field of criminal cases, her struggles with the patriarchal values will also be discussed in this study. Thus, in this paper, Miss Marple's efforts to enlighten the murder, her overcoming the prejudice against women and her prevailing over male-domination will be analyzed.
\end{abstract}

Keywords: Detective Novel, Agatha Christie, Female Detective, Miss Marple, The Body in the Library

\section{Introduction}

Agatha Christie, one of the most popular authors of detective novel, contributed to the development of detective fiction by means of her stories, mysteries, spy thrillers and novels. Miss Marple, one of the most popular detectives of Christie, comes to the fore in many novels of the author: One can recognize the female character, Miss Marple in Christie's works such as in The Murder at the Vicarage (1930), The Body in the Library (1942), A Murder is Announced (1950), A Pocket Full of Rye (1953), The Mirror Crack'd from Side to Side (1962), A Caribbean Mystery (1964), At Bertram's Hotel (1965), Nemesis (1971), Sleeping Murder (1976) (Drabber and Stringer, 2007, p.134). The most significant aspect in these works is that the detective, Miss Marple attains success and solves the mysteries owing to her female identity. In this article, the stereotyped role of women as submissive, passive, distressed, waiting to be rescued by a male, which was created by the male-dominated nineteenth century society, will be questioned and rejected through the analysis of Miss Marple as a successful and powerful female detective. Thus, the binary opposition affirming the inferiority of women and superiority of men will be destroyed.

\subsection{The Importance of Gender in Mystery Solving}

Considering Christie's Miss Marple novels, including The Body in the Library, it is obvious that these works acquire very significant qualities in terms of the methods employed during the process of the female detective's solving the puzzle. Moreover, the relationship between the police officers and the female detective, Miss Marple, who is an amateur detective, is worth analyzing. Despite the prejudice of the male-dominated society, she achieves revealing the truth about the mystery behind the murder in the work. How she attains knowledge about the crime is based on her taking each detail into consideration. Therefore, particularly in Christie's Miss Marple novels, "[n]o-one is unimportant [...]. Victim, suspect, witness, gossip, policeman, detective - all have a part to play in the puzzle which has to be solved" (Underwood, ed., 1990, p. 47).

\section{The Distinctive Characteristics of Miss Marple as a Female Detective}

\subsection{Miss Marple's Power of Observation}

As an old female, the stratagems Miss Marple uses in The Body in the Library, to solve the mystery and to find the criminals, differ from the male detectives, since she gives priority to the triviality of everyday life in the village, the details about the physical appearance of people by focusing on the significant characteristics of human nature, therefore 
she is very good at discovering the undiscovered world of both women and men through her detailed observations, investigations and by means of the "dominating 'eye' of the private detective" (Catano, 2000, p. 435), as a result of which she achieves identifying the guilty from the innocent as Shaw and Vanacker (1991) stress: "[...] what the Miss Marple novels propose is that there is a logic which is structured around the minutiae of life which can nevertheless inexorably reach into the very depths of human society and the human psyche. And they suggest that women, particularly old women, because they are attuned to the trivia of existence, are therefore endowed with logical powers which make them ideal arbiters of justice [...]" (p.34). In this sense, in a logical manner, her analyzing the basic features and the trivial aspects of her society and the important clues about human psychology enables her to eliminate chaos in society, to establish order and to find out the mystery behind criminal cases. Thus, it should be emphasized that her being a member of the society illustrated in Christie's novels, is also of great importance and strengthens her ability to reveal the criminals. Since she comes from the village and belongs to the setting in which the crime has been committed, she can see the inner world of the ordinary characters, their life style and their typical characteristics. Hence, it should be highlighted that "[...] Agatha [also] wanted her ordinary life [...]. She enjoyed it for its own sake, and it was essential to her writing; her drug, in a way [...]" (Thompson, 2007, p. 307), as a consequence of which her amateur sleuth Miss Marple can reach realities about crimes by focusing on the attitudes, gestures, facial expressions of people in society. As Sova (1996) also underlines: "[...] those who really know her recognize that she is a sharp observer of human nature. [...] her village and its environs contain every type of character trait and evil in human nature [...]. [H]er method of detection consists in finding parallels between life and people in St Mary Mead and happenings in the outside world, no matter how gruesome" (p.209). It is clear that her observing parallel aspects between the inner side of individuals and the outside events leads her to identify the unexplored link between the actions of people and their life in community. In this respect, in Christie's The Body in the Library (1942), Miss Marple comes into view as a sharp observer of this relationship as seen: "[...] Miss Marple had attained fame by her ability to link up trivial village happenings with graver problems in such a way as to throw light upon the latter" ( $B$ in the $L$, p.15). Thus, a crime that cannot be enlightened by the others is effectively solved by Miss Marple, who succeeds in collecting the necessary data to reveal the mystery of the crimes she has been asked to investigate.

\subsection{Miss Marple's Establishing Morality and Order as a Female Detective in a Patriarchal Society}

In The Body in the Library, dwelling on the psychology and the physical appearance of the suspected, she also achieves attaining the reality about the dead body found in a library. While the way the mystery is solved by the female detective is different, the structure of the story is similar to the elements of classic detective fiction as can be seen: the whodunit tradition, a specific formula, a murder committed invisibly, a person finding the body, investigation with many suspects, confusions within the process of finding the truth, the importance of speech and gesture to reveal the reality (Wagoner, 1986, pp. 33-35). Considering the fact that the novel was published after World War I, it is also clear that Christie deals with "escape literature" (Wagoner, 1986, p. 66) by giving the power to an eccentric female character, Miss Marple, to defeat the evil and to establish morality and order in a village. However, what is extraordinary is that it is a female who achieves stopping the chaos in society, thus the power of the evil is eliminated by a female detective in most of the detective novels of Christie as well as in The Body in the Library. In this manner, in a male-dominated society, a female's having the ability to establish morality in society and to punish the wicked also draws attention. Therefore, though some critics define detective novels as being "read and [written] for pleasure" (Freier, 2004, p. 190), in fact particularly Christie's Miss Marple detective stories have a specific formula and a detailed portrayal of characters together with the focus of the female inspector on the behaviours, talking manners, psychological states of the characters, consequently the impact of these elements upon the suspects' committing crime is effectively exposed by a woman in a patriarchal community.

\subsection{Miss Marple's Success in a Male-Dominated Society}

Paying attention to the development of the story in The Body in the Library, it is seen that Miss Marple tries to find the murderer of Ruby Keene, a dancer, gets information from the suspects, analyzes their body language, hesitant manners, and finds the reality that the policemen cannot attain. She is depicted as an amateur sleuth who is "so good at bodies [...], [and] very good at murders" ( $B$ in the $L$, p. 9). Investigating the relationship between Ruby Keene and the persons she has close contact with, Miss Marple reveals the mystery behind the murder. In this respect, as Merrill also indicates, the typical characteristics of Christie's detective novels can also be seen in The Body in the Library. Most of her detective novels consist of female detectives trying to gain information about a crime through clues, details, observations and investigations and explaining the result they arrive at the end (pp.87-88). Considering the function of Miss Marple in Christie's novels, although "Miss Marple is almost never the primary investigator" (Merrill, 1997, p. 95), owing to her potential to identify the details the others have ignored, she has a very considerable contribution to solving the uncertainties behind the crimes, so she challenges the male detectives and attains success despite the biased views about women.

\subsection{Miss Marple's Focus on the Psychology of People in her Quest of the Murderer}

In The Body in the Library, the story starts when the body of a girl is found in Colonel Bantry's library and it continues with the investigation related to this body. As Gerald (1993) points out, "[d]evotees of Agatha Christie's fictional works know and have come to expect that [...] the reader is typically presented with a rather cold body that has been murdered offstage and out of sight" (p.4). Consequently, instead of violence and bloody sections, the process of solving the mystery is at the centre of the story. In this manner, it should be stated that while the policemen cannot solve the puzzle, it is Miss Marple, who sheds light to the ambiguity of the dancer's death, because as Barnard (1990) also states, Miss 
Marple is "sharp-eyed, sharp-tongued, a vicious gossip with an incomparable information service and a desire to believe the worst" (p.96). Her focus on the psychology of the suspects while attaining information from them through meetings, her concentrating on the gossips in the village revealing the psychological mood of people and her realizing the wrongs with these people by questioning their statements, make her more powerful than the professional male detectives, who are unable to recognize the complexities of human nature and the relationships among these people. Thus, as Cooper (1989) underlines, the detective's "[...] search for 'the facts' [...], [the] quest for knowledge would seem consistently to imply [the] wish [of the investigator] for the kind of personal power [...] [in] the fragmented world of mystery" (p.23). Accordingly, Miss Marple holds the power in her own hands through her search for knowledge, which will display the psychology of suspects. In this respect, Miss Marple, paying special attention to the psychological state of people, understands that there is something wrong with the attitudes of Josie Turner as she says: "Did you notice that when you asked her if she wasn't anxious about the girl being missing, she said that she was angry? And she looked angry - really angry! [...]. She didn't care for her, I'm sure. She's not grieving in any way. But I do think, very definitely, that the thought of that girl, Ruby Keene, makes her angry" (p.53). It is apparent that Josie's unexpectedly becoming angry, rather than grieving for the murder of Ruby, in other words her reaction towards the death of her cousin, makes Miss Marple to dwell on the strange manners of this girl. It proves that "Miss Marple is a structuralist detective; having in mind a structure of human types, which she has learned from the study of her village community [...]" (Shaw \& Vanacker, 1991, p. 74). Taking the human types into consideration, Miss Marple, though being regarded as an ordinary, insignificant spinster, comes into sight as the one to discover the secrets of the criminal investigations. In this outlook, the discrepancy between her physical depiction in the novel and her intelligence should be taken into account as observed: "[...] there sits an old lady with a sweet, placid, spinsterish face and a mind that has plumbed the depths of human iniquity and taken it as all in the day's work. Her name's Miss Marple. She comes from the village of St. Mary Mead [...]" (p.103). Consequently, although she is considered to be an old spinster whose talent for revealing the crimes is underestimated, at the end it is recognized that she has the ability to achieve success in criminal cases through her logical observations on the psychological condition of people. She indicates the difference between her own methods and those of the professionals as recognized: "I'm afraid you'll think my methods, as Sir Henry calls them, are terribly amateurish. The truth is, you see, that most people - and I don't exclude policemen - are far too trusting for this wicked world. They believe what is told them. I never do. I'm afraid I always like to prove a thing for myself" (p.210), thus she refers to her distinctive methods, which distinguish her from the typical male detectives.

Miss Marple's underlining the evil in human nature and her focus on the importance of continuous interrogation of human psychology, despite the facts already attained, show that she can see what the others cannot. Nevertheless, it is not easy to eliminate the inequality between female sleuth and male detectives. Therefore, in The Body in the Library, one can see the prejudice of the male-dominated society towards the females, so Conway Jefferson thinks that Miss Marple is successful because of "woman's intuition," but in the novel Miss Marple says that her talent comes from "specialized knowledge" (p.103). So, according to the norms of the patriarchal society that repress women, females cannot investigate, cannot be rational or reasonable, in other words intelligence is attributed to males. Ironically enough, despite the fact that patriarchal community degrades her power, it is also patriarchal society that has no alternative but to rely on her talent. Hence, the professional male investigators also admit that they are unable to expose the reality. While Colonel Melchett says, "[w]e can’t make a case against anybody" (p.138), Superintendent Harper indicates, "[we are] [n]owhere, sir" (p.139).

\subsection{The Role of Female Instincts and Emotions in Miss Marple's Solving the Mystery}

Regarding the female detective's following what her heart says, it is important to note that it is Miss Marple who discovers another murder by means of her intuition, the murder of young Pamela Reeves, whose body is replaced with the body of Ruby Keene, so when Sir Henry says, "You think a second murder?", she replies: "Why not? [...]. When anyone has committed one murder he doesn't shrink from another, does he?" (p.136). Thus, she reveals the fact that while the body found in the library is Pamela Reeve's body dressed in Ruby's clothes, the body dressed in Pamela's garments and found in George Bartlett's car is in fact the body of Ruby Keene. The ambiguity is clarified by Miss Marple, who relies on her emotions as a female, so she pays special attention to the importance of female instincts. She realizes that Mark Gaskell, the son-in-law of Mr Jefferson, learning Mr Jefferson's plan to adopt Ruby as his daughter and to give her his money and properties, planned the crime with Josie Turner, his wife, though it is not revealed till the end. Therefore, it is clear that Miss Marple knows the intentions, stratagems and motives of people to commit crime as seen in her own words: "Money is a very powerful motive" ( $B$ in the $L$, p. 166), which shows people's obsession with gaining wealth and property through crime in detective novels. Therefore, the impact of capitalism, the power of money, the basic elements of murder in the classical detective novels can also be seen in Christie's works as Gerald (1993) asserts: "[The] murderers have been motivated [by] [...]: money or other material gain; fear of being exposed as a murderer or losing one's social position [...]" (p.47). It is doubtless that the same situation is also observed in The Body in the Library, but rather than the motives of people, Miss Marple's methods to solve these motives draw attention. For example, as she knows the human nature well, she collects information related to the intentions and attitudes of the suspects and makes use of them. As Agassi (1982) suggests, "the detective collects as much information as he can and then surveys it over and over since there is no knowing what might be the telling clue" (p.100). In this respect, Miss Marple, being aware of the fact that even the slightest movement of each suspect is very important, she is in a constant quest for information. In this manner, she also realizes something wrong with Mark Gaskell when she analyzes his dialogue with Adelaide Jefferson: 
Mark: "We thought there was no harm in her [Ruby]. No harm in her! I wish I'd wrung her neck." "Mark," said Addie, "you really must be careful what you say." "I suppose I must. Otherwise people will think I actually did wring her neck. Oh, well, I suppose I'm under suspicion anyway. If anyone had an interest in seeing that girl dead, it was Addie and myself." (p.117)

Though he reveals his hatred towards Ruby and emphasizes that he is not distressed for her death, he pretends not to commit the crime, and accuses the policemen of their dwelling on his financial troubles by indicating:"[...] I'm Favorite Suspect Number One to the police! They've been delving into my financial troubles. I'm broke [...]" (p.149). In this respect, Miss Marple, bringing all the bits and pieces together from different suspects, turns out to be more successful than the professional investigators, because as she also underlines: "The trouble in this case is that everybody has been much too credulous and believing. You simply cannot afford to believe everything that people tell you [...]. I never believe anyone at all. You see, I know human nature so well" (p.170). It proves that doing her best to catch the clues about people considering the depth of human nature, instead of believing any story they tell, she achieves success. As Hark (1997) also highlights, Christie's believing the fact that "human guilt and innocence are thoroughly intermixed" (p.112) enables her to create Miss Marple, who also supports the same philosophy by dwelling both on the moral and the immoral values of the suspects. Thus, she ignores neither her own feelings nor the feelings of the suspects.

\subsection{Miss Marple's Concentration on Outward Appearance and Trivial Issues}

Miss Marple's analyzing the clues about the victim's physical appearance, her clothes, and the parts of her body also plays a very important role in her deducing significant information. Examining the garment of the dead girl, she realizes that the condition of her dress may reveal a secret, because it is not a proper dress of a girl who will meet a guy after her dance show:

There was the dress. The dress was all wrong. [...] it was an old dress, $[\ldots]$ and I could see for myself that it was shabby and rather worn. Now, that's all wrong [...]. Why was she wearing an old dress? The superintendent: "I see your point. You think she'd wear a new one?" Miss Marple: "I think she'd wear her best dress. Girls do.” (p.158)

As a female detective, she pays attention to the details about girls and their wearing styles, which makes her question the improper old dress on the dead body. While the superintendent cannot realize the importance of this detail, Miss Marple finds out a very important clue about the mystery. As a woman, she knows that girls wear their best garments if they have a rendezvous. However, as a male, Sir Henry emphasizes: "Suppose she was going outside to this rendezvous. Going in an open car, perhaps, or walking in some rough going. Then she'd not want to risk messing a new frock and she'd put an old one" (p.159). On the other hand, Miss Marple, as an experienced female and a very good observer of physical appearance, indicates: "If she were meeting him inside the hotel or somewhere where evening dress was worn, she'd wear her best evening frock, of course, but outside she'd feel she'd look ridiculous in evening dress and she'd wear her most attractive sportswear" (p.160). Her remark justifies that a female detective has more power than a male in terms of observing the trivial things that can explain a hidden truth. In this manner, she also recognizes something wrong with the fingernails of the victim, because generally girls who have make-up have long fingernails, but the condition of the dead girl's fingernails is just the opposite. After learning that Ruby caught her nail in Josie's shawl and cut it, Miss Marple concentrates on the difference between the bitten and the close-cut nails of the two bodies, as a consequence she discovers, by means of this detail, the body in the library is not the body of Ruby Keene, but of Pamela Reeves, whereas the body burnt in the car is in fact Ruby's body. In this respect, even the most insignificant detail is very important not only for Miss Marple but also for Christie's readers who want to attain reality. Therefore, Barnard likens Christie's detective fiction to a "child's colouring book" (p.112), which will be shaped and colored by the female detective and the readers who are supposed to fill in the gaps with the details and various facts, in other words, with different colors, so as to give a specific meaning to the outline. In this respect, the stratagems Miss Marple employs to reveal the truth help the readers follow the plot and be involved with the mystery.

\subsection{Miss Marple's Empathy with Female Characters: Its Contribution to her Success}

It is no doubt that her being an amateur female detective in a male-dominated community is an obstacle for her, because she devotes her time and energy not only to prove the guilt of the suspect but also to persuade the professional male detectives and policemen to believe in her observations and suggestions. What the others ignore about her is that she is as talented as male detectives and she does her best not to overlook the basic differences between women and men and not to disregard the general characteristics of female suspects and victims. For example, in order to solve the secret about the murder of Pamela Reeves, she wants to get information from the girls who may reveal the mystery. In this respect, among the other girls, her choosing Florence Small, who is "twisting her hands and look[ing] nervous" (p.180) also shows her ability to see the hesitant and nervous manners of the girl, in other words her talent to observe the depths of human nature and the basic characteristics of women. Thus, Superintendant Harper indicates: "I feel Miss Marple's the person to get it out of these girls. I'd say she knows a thing or two about girls" (p.157). Miss Marple, stressing her ability to perceive the realities women hide, emphasizes the importance of her observations over the typical characteristics of females and her experiences with women: "I've quite a lot of experience in when a girl is speaking the truth and when she's holding something back" (p.157). Therefore, the difference between Miss Marple and the professional male investigators is that while she spends most of her time with ordinary people, the policemen are the 
outsiders who try to expose the inside of people. Hence, even if she is regarded, by the male-dominated society, as an old spinster who cannot be as powerful and intelligent as men, in fact she is the one who protects the values in society and creates order out of chaos. On the other hand, since her power is not recognized, she is depicted by the narrator in this manner: "In the corner of Superintendent Harper's office sat an elderly lady. The girls hardly noticed her. If they did they may have wondered who she was. She was certainly no police matron. Possibly they assumed that she, like them, was a witness to be questioned" (p.179). Although as a detective she is there to question the girls, she is not considered to be a sleuth, but a witness who will be questioned for the case. However, her "standing between the lawbreaking and the law-abiding world" (Woods, 1997, p. 105), her skill in deeply, logically and objectively analyzing the information she has gained from all of the suspects, enable her to reach a solution and to make men shocked.

Despite the prejudice of patriarchal society, when one considers her ability to identify the mystery behind the crime, Miss Marple comes to the fore as a female who is more powerful than professional male sleuths. Through logical analysis and sharp observations, she reveals the secrets. As Hart also points out, Miss Marple, attaining conclusions through the data she collects, "was able to disentangle the most complicated misdirections her villains could devise: false identities, impersonalities, double bluffs, misleading incidences [...]" (140-41). As a consequence, the readers, following the clues Miss Marple finds and inquiring the facts like a detective, also try to identify the murderer in spite of the distorted facts; in this outlook Miss Marple plays a significant role in attracting the attention of readers. Thus, instead of the emphasis on horror and bloody scenes, the focus is on the methods employed by the female detective to enlighten the ambiguity. During this process, it is Miss Marple who makes the male detectives surprised due to the effective techniques she uses. Miss Marple's choosing Florence Small among many girls and attaining information about Pamela Reeves make Superintendent Harper astonished, so he says: "What put you on to this particular girl? They all looked scared to death and there wasn't a pin to choose between them, as far as I could see" (p.185). It is obvious that he appreciates her talent and wonders how she managed to choose her, which shows the difference between female and male perception. It is no doubt that Miss Marple's own experiences and her profound analysis related to women contribute to her success as she suggests: "You haven't had as much experience with girls telling lies as I have. [...] you didn't watch her as she went out of the door. I knew at once then that she'd got something to hide" (p.185). It would not be wrong to assert that she does not investigate individuals on the surface, but she centers on each movement, attitude and expression of people in their ordinary and private life without ignoring their gender. In this respect, what is of importance is that rather than strange characters, common people dominate Christie's work, like Miss Marple, who is an ordinary sleuth with extraordinary skills, because Christie "confined herself to what she knew and, by extension, what she could most easily imagine" (Osborne, 1990, p. 193), so her own observations about people in her community initiated the development of her detective novels and changed the perspective of patriarchal society to women and their capabilities.

Miss Marple, representing the intelligence of women and their undeniable function in establishing order, is also good at identifying the social activities women are acquainted with. In this sense, her meeting with Dinah Lee, the wife of Basil Blake, who is accused of the murder of the girl, comes to the fore, because Miss Marple, knows that "collecting moral and financial support, [for certain institutions and for people suffering from poverty], was an important social activity" for the females in the village (Hart 8), so she uses this method and knocks the door of Basil Blake's wife and gets detailed information. It is clear that being a part of the community in which a crime has been committed, Miss Marple, as an amateur detective, solves even the most complicated mysteries. Thus, as Grella (1970) asserts,

The amateur detective, conversely, always is socially acceptable and comprehends the code of the society he investigates - he can question with delicacy, notice 'bad form,' or understand lying like a gentleman to the police; therefore he always triumphs over the mundane ways of the official forces of law and order. (p.34)

Thus, Miss Marple, as an amateur sleuth, is also aware of the social norms, life styles, and the habits of people in her own society, as a consequence of which she has the ability to identify the 'good' from the 'bad', or the 'honest' from the 'dishonest.' Her witnessing the close relationship between the individual and society gives her the power and the knowledge to find out the mystery about crimes. Therefore, as Ackershoek (1997) also emphasizes, Marple draws her power from "information gathering through the homely means of gossip and observation of seemingly minor details of domestic life and human behavior" (p.121), as a result of which rather than the professional sleuths, she is the one who attains the truth. Hence, it is apparent that Miss Marple, with this method, manages to solve the puzzle and finds the murderers.

\section{Conclusion}

Finally, as an old lady, having experienced a lot and recognizing not only the human nature but also the most significant aspects of her community, the village, she lives in, Miss Marple has the talent to question and learn where, when, why something took place, by interrogating the conflict between morality and immorality, analyzing both the physical and the psychological state of characters and considering the discrepancies between women and men. Since she has many experiences through her contacts with different people in society and through close scrutiny, she manages to solve even the most complicated crimes. In this sense, Agatha Christie, creating Miss Marple and giving her the power and the intelligence to compete with the professional male sleuths and even to surpass the talent of specialized male investigators, breaks the barriers in front of the females repressed by the male-dominated society. Moreover, by portraying the mystery about a criminal case in a village, she deals with the elements of classical detective novels in 
which evil is destroyed and order is established. On the other hand, what makes her work unique and distinctive among the classical detective fiction is that the classical elements of detective stories are combined with the incredible talent of a female detective, who competes with the success of male investigators and achieves superiority among the male sleuths. Thus, Christie's amateur female detective Miss Marple comes into view as a successful sleuth, who preserves the harmony in society by overcoming the guilty and supporting the victims, so among the professional male detectives, it is her who achieves revealing the reality about the criminal cases; as a result in a male-dominated setting, Christie foregrounds the wisdom, intelligence and the power of a female detective, who has the potential to triumph over the supremacy of male-domination.

\section{References}

Ackershoek, M. A. (1997). The daughters of his manhood: Christie and the golden age of detective fiction. In Jerome H. Delamater and Ruth Prigozy (Eds.). Theory and Practice of Classic Detective Fiction (pp. 119-128). London: Greenwood P.

Agassi, J. (1982). The detective novel and scientific method. Poetics Today. 3(1), 99-108 Retrieved from http://www.jstor.org/stable/1772208.

Barnard, R. (1990). A talent to deceive: an: appreciation of Agatha Christie. London: William Collins.

Catano, J. V. (2000). Detecting change: gender and ethnicity in the detective novel. Novel: A Forum on Fiction. 33(3), 432-39 Retrieved from http://www.jstor.org/ stable/1346176.

Christie, A. (2000). The body in the library. 1942. New York: Signet.

Cooper, S. (1989). Sex, knowledge, power in the detective genre. Film Quarterly. 42(3), 23-31 Retrieved from http://www.jstor.org/stable/1212598.

Drabble, M. \& Stringer, J. (Eds.). (2007). Oxford concise companion to English literature. Oxford: Oxford UP.

Freier, Mary P. (2004). A brief history of scholarly study of detective fiction, with particular attention to the detective and mystery fiction area of the popular culture association. Collection Management. 29 (3-4), 189-196 Retrieved from http://dx.doi.org/10.1300/J105v29n03_14.

Gerald, M. C. (1993). The poisonous pen of Agatha Christie. Austin: U of Texas P.

Grella, G. (1970). Murder and manners: The formal detective novel. Novel: A Forum on Fiction. 4(1), 30-48 Retrieved from http://www.jstor.org/stable/1345250.

Hark, I. R. (1997). Impossible murderers: Agatha Christie and the community of readers." In Jerome H. Delamater \& Ruth Prigozy (Eds.), Theory and practice of classic detective fiction (pp. 111-118). London: Greenwood P.

Hart, A. (1990). The life and times of Miss Jane Marple. London: Sphere Books Limited.

Merrill, R. (1997). Christie's narrative games: predecessors and pursuits of a postmodern detective novel. In Jerome H. Delamater \& Ruth Prigozy (Eds.), Theory and practice of classic detective fiction (pp. 87-102). London: Greenwood P.

Osborne, C. (1990). The life and crimes of Agatha Christie. London: Harper Collins P.

Shaw, M., \& Vanacker S. (1991). Reflecting on Miss Marple. London: Routledge.

Sova, D. B. (1996). Agatha Christie a to z: the essential reference to her life and writings. New York: Facts on File.

Thompson, L. (2007). Agatha Christie: an English mystery. London: Headline.

Underwood, L., ed. (1990). Agatha Christie: official centenary celebration 1890-1990. Glasgow: Cellins P.

Wagoner, M. S. (1986). Agatha Christie. Boston: Twayne P.

Woods, R. (1997). It was the mark of Cain: Agatha Christie and the murder of the mystery. In Jerome H. Delamater \& Ruth Prigozy (Eds.), Theory and practice of classic detective fiction (pp.103-111). London: Greenwood P. 